\title{
Internet readiness and e-Business adoption of Canadian value-added wood producers
}

\author{
by Robert A. Kozak ${ }^{1}$
}

\begin{abstract}
This study focuses on results of a facsimile survey sent to value-added wood producers across Canada on their levels of Internet readiness and electronic business (e-Business) adoption. In addition, attitudinal information was collected with respect to companies' willingness to use the Internet as a business tool to facilitate exchange along the supply chain. Findings indicate that, while the use of the Internet is relatively commonplace, the Canadian value-added wood products sector has yet to embrace high level e-Business tools on a wide scale. However, there is a willingness to do so and results clearly point to the fact that most manufacturers expect the Internet to become increasingly important in the context of day-to-day business applications.
\end{abstract}

Key words: value-added wood products, Internet, e-Business, e-Commerce

Cette étude se concentre sur les résultats d'un sondage par télécopieur acheminé aux producteurs de bois à valeur ajoutée de tout le Canada sur leur niveau d'adoption de l'utilisation de l'Internet pour leur commerce électronique. De plus, de l'information sur leur attitude a été recueillie en ce qui a trait à la volonté des entreprises d'utiliser l'Internet en tant qu'outil d'affaires pour faciliter les échanges le long de la chaîne d'approvisionnement. On relève de ce sondage que, même si l'utilisation de l'Internet est relativement courante, le secteur canadien des produits de bois à valeur ajoutée se doit encore d'utiliser les outils du commerce électronique sur une grande échelle. Cependant, il existe une volonté de faire en ce sens et les résultats illustrent clairement que la plupart des manufacturiers croient que l'Internet deviendra de plus en plus important dans le contexte des applications de commerce au jour le jour.

Mots-clés: produits de bois à valeur ajoutée, Internet, échanges électroniques, commerce électronique

\section{Introduction}

It goes without saying that the Internet is fast becoming part of our collective psyche. The business community is by no means immune from this seemingly never-ending wave of technology as it enters into an era that has commonly been dubbed the "new economy." Despite recent setbacks in the "dotcom" industry, it is estimated that the volume of Internet-based electronic business (e-Business) will exceed one trillion dollars by 2003 , with the vast majority of transactions being attributed to business between companies, as opposed to consumer sales (Forrester Research 1999). The term "e-Business," generally synonymous with "e-Commerce" (electronic commerce), is difficult to define. At the simplest level, it refers to the use of Internet technologies to support companies' business activities and functions. More specifically, it encompasses the provision of extensive information content, diverse communications services, electronic commerce capabilities and hosted business applications, to name a few key examples.

Because the Internet and Internet use are so rapidly evolving, it is difficult to determine current levels of business use. That said, one recent benchmarking study attempted to characterize Internet business use with respect to demographics and behaviour (Clemente 1998). It was estimated that corporate users account for $33 \%$ of all Internet users and that, in this context, the Internet is primarily being used for content acquisition, online research and document exchange. Nearly two-thirds of adult users of the Internet utilize it for some business purposes while one-third use it more than half of the time for this purpose. While most business users have access to high-speed Internet connections, it is small businesses (less than 100 employees) that currently dominate the Internet business landscape, accounting for over $40 \%$ of all business users and growing. Mid-size companies-100 to 1000 employees-

${ }^{1}$ Assistant Professor, Department of Wood Science, Faculty of Forestry, University of British Columbia, Forest Sciences Centre, 4041 - 2424 Main Mall, Vancouver, British Columbia V6T 1Z4. E-mail: rkozak@interchg.ubc.ca account for just over $20 \%$ of all business users (upward trend), large companies-over 1000 employees-account for just less than $30 \%$ of all business users (downward trend), while the remainder is attributed to the emerging home-based business sector (upward trend).

The fundamental question driving this research revolved around understanding how the forest products industry is adapting to the new economy.

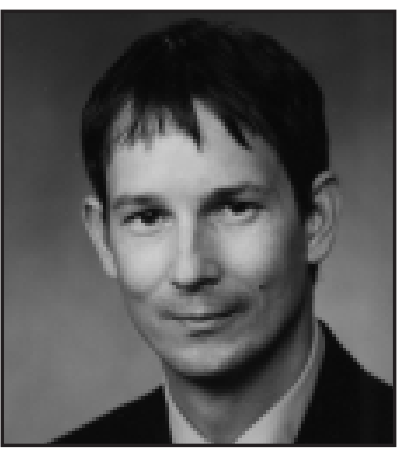

Robert A. Kozak While a great deal of research has been conducted on understanding this problem in the context of the primary forest products sector (pulp and paper, lumber, panels, etc.), very little work has been focussed on better understanding the specific needs of secondary wood producers. This paper discusses the results of a survey on Internet use and e-Business adoption sent to over 1000 Canadian value-added wood products manufacturers, the purpose of which was to quantify their level of Internet readiness and e-Business adoption.

\section{Background}

Broadly defined, the term "value-added" refers to wood products companies that add incremental value to products either

\footnotetext{
$\overline{{ }^{2} \text { Arguably, the term value-added can and should apply to manufacturers of }}$ commodity wood products like dimension lumber and pulp and paper. While commodity wood producers do little in the way of product differentiation and/or additional manufacturing, value is intrinsically being added by each primary processing step. Value-a function of price and perceived benefits - depends largely on the particular needs and wants of various customer groups. As a result, the term "value-added" in this paper refers to products that may yield higher prices, but do not necessarily improve the value of wood products. It can, for the most part, be interchangeably used with the term "secondary wood products."
} 
by primary manufacturing in saw and planing mills (resawing, surfacing, drying, or otherwise differentiating lumber products) or by secondary manufacturing in separate processing facilities (furniture, case-goods, and home systems being some examples). ${ }^{2}$ Value-added wood products generally fall under one of the following categories:

- remanufactured wood products;

- shakes and shingles;

- pallets and boxes;

- fences;

- miscellaneous other products (toys, ladders, etc.);

- engineered wood products;

- mouldings, millwork and floors;

- doors and windows;

- cabinetry;

- furniture; and

- home systems.

The manufacture of value-added wood products accounts for a large and growing sector in Canada's economy. Of the $13 \%$ that the forest industry contributes to Canada's gross domestic product annually, value-added wood products account for over one-quarter or CDN $\$ 10$ billion in shipments, with more than half of this being accounted for by primary levels of value-addition (Industry Canada 2001) ${ }^{3}$. While this is small relative to the ubiquitous lumber and pulp and paper industries, it is nonetheless an important sector, accounting for approximately $20 \%$ (45 000) of the forestry-related jobs and over half (1900) of the manufacturing establishments (Industry Canada 2001). Value-added processors tend to be smaller, less capital-intensive and less rurally based than their primary lumber producing, upstream cousins. In addition, value-added wood products manufacturers are among the most profitable enterprises in Canada's forest industry, producing a wide range of products and values (Statistics Canada 1998).

It is also noteworthy that the Canadian value-added sector is in the midst of a growth surge. Over the last ten years, clear upward trends can be observed in manufacturing levels for kitchen cabinets, wooden doors and windows, millwork and mouldings, and wooden household furniture, to name a few examples (Statistics Canada 1998). This is due, in no small part, to rapidly expanding exports as markets in the United States, Japan and Europe open up. In the last five years, exports of various value-added wood products have increased at rates of between $25 \%$ and $40 \%$.

Despite its growth, the forest products industry has been notably slow in its adoption of Internet strategies as a means of conducting business. Unlike other industries that have adopted, implemented and deployed e-Commerce solutions, it remains to be seen whether or not the Canadian value-added wood products sector has embraced information technology (IT) to support its business functions on a wide scale. Unfortunately, very little has been done in the way of research pertaining to Internet use in the forest industry, and specifically amongst value-added wood producers. One notable exception is the work of Vlosky (Louisiana State University), who has published numerous papers on the subject.

In 1997, Vlosky and Fontenot surveyed 364 US forest products companies from both the primary and value-added sec-

\footnotetext{
${ }^{3}$ While this study does not explicitly deal with value-added production in the United States, it should be noted that this sector contributes over CDN \$50 billion to its economy.
}

tors and concluded that Internet use in the forest products industry was expected to grow rapidly and that companies that developed an Internet strategy would possess a marked competitive advantage. While over half of the companies surveyed had Internet access at the time, only one-third of the value-added wood producers did. Less than one-third of the wood producers had a Web site at the time, but of these, more than half were value-added producers. In addition, many of the companies that did not have a Web presence seemed averse to the idea. That said, the study concluded that the most likely users of the Internet in the forest products industry were either small companies with less than $\$ 1000000$ in sales or valueadded wood producers (Vlosky and Fontenot 1997).

The primary uses of the Internet cited in the Vlosky and Fontenot study were for e-mail, customer contacts and product promotion. The predominant Internet business application, according to wood producers, was, and was also expected to be, sales. However, the researchers found that as company size increased (especially beyond $\$ 1000000$ ), the likelihood of using the Internet to facilitate sales dropped precipitously. In the final analysis, over half of the companies surveyed were willing to sell goods over the Internet, but just one-quarter were willing to purchase goods. Only $10 \%$ indicated that they were not willing to participate in e-Commerce. Other important Internet business applications for wood producers included the ability to enable product and price inquiries for customers. The major benefits that wood producers expected from having a Web presence were customerrelated: a greater exposure to customers and greater access to their company by potential customers. These were followed closely by increased access to vendors, timeliness of information exchange, and an enhanced image (Vlosky and Fontenot 1997).

Vlosky's 1999 follow-up study differed somewhat methodologically in that pulp and paper producers and manufacturers in Canada were also included. Furthermore, solid wood producers were not explicitly segmented into primary and value-added manufacturers (results for pulp and paper and solid wood producers were reported in aggregate). In total, 207 wood products companies were surveyed from across North America. Findings indicated that $60 \%$ of the companies did not use the Internet as a means of conducting business at that time. In addition, over one-half of these respondents stated that they had no intention of doing so in the near future, although larger companies were more inclined to adopt Internet technologies than smaller companies, contradicting Vlosky and Fontenot's 1997 results somewhat. The majority of those producers that have embraced e-Business had done so in the three years prior to the study. However, well over half of the respondents have invested less than $\$ 50000$ for e-Business applications. Despite some discouraging results, it can be argued that, while the forest products industry is a laggard industry, it is poised to adopt Internet business solutions (Vlosky 1999).

In Vlosky's 1999 study, wood producers that currently had adopted Internet technology to facilitate business transactions were asked about the e-Business applications that they use or will use in the very near future. They cited customer contacts, Web pages and marketing as the most common uses, followed by vendor contracts, product promotion, product / price inquiries and customer sales (these latter two seem to have decreased in importance since the 1997 study). The primary benefits of conducting e-Business included increased access to industry information, timeliness of information exchange, 
greater exposure to potential customers and greater access to companies by potential customers. On the other hand, wood producers seem to be acutely concerned with security and the exchange of sensitive information (Vlosky 1999).

Data from Vlosky's 1999 study was also used in a 2001 follow-up by Vlosky and Pitis, which compared e-Business capabilities of wood products companies in Canada versus the United States. The study found that businesses in the two countries are very much alike with respect to Internet use, with Canadian companies being slightly less concerned with the longrun potential for the Internet as a commerce tool. Although valueadded producers were not explicitly surveyed, the results bode well for the Canadian wood products industry. As of 1998, 94\% of the Canadian companies surveyed had implemented some form of Internet technology, compared to $85 \%$ for the United States. Approximately three-quarters of the Canadian wood producers surveyed used the Internet to conduct business, compared to just a little more than one-half in the United States. Of the companies that did not use the Internet for business purposes, $69 \%$ of the Canadian companies planned on doing so in the future, compared to only $34 \%$ in the United States. These results are confounded somewhat by the fact that Canadian respondent companies were generally larger than their US counterpartsmost were primary wood producers and panel manufacturers. That being the case, it is difficult to apply these results to the value-added wood products sector (Vlosky and Pitis 2001).

As expected, forest industry consultants have also been at the forefront of conducting research pertaining to e-Business in the forest products industry. PriceWaterhouseCoopers (PWC) indicates that the traditional value chain is rapidly being replaced by value networks in which e-Business allows companies to concentrate on their core competencies. The forest products industry is lagging behind other sectors in this transformation and needs to quickly respond to these changes. This point resonates in a PWC study, which ranked the top 100 forest and paper companies Web sites according to functionality, strategy and visual impact. Of a possible score of 100, only five companies rated more than 75 points, while only nine companies rated over 50 points (PriceWaterhouseCoopers 1999). In addition, a related press release stated that, "The rise of e-Business infomediaries will fundamentally affect companies revenues and profits in the near term...The winners in the [forest products] industry will be companies that can reduce costs and get closer to customers. E-Business is the vehicle that will help level the playing field and provide innovative companies the opportunity to excel." (PriceWaterhouseCoopers Press Release 2000).

Results from a recent Ernst \& Young press release on a survey of Information Technology in the retail sector are also both revealing and germane to the wood products sector. Nearly twothirds of the retail executives (from large corporations) surveyed believe that e-Commerce is the top priority, while three-quarters believe business-to-business e-Commerce is a definite priority. The release goes on to say that, "US retailers are creating sites for Canadian customers... [which] will directly affect Canadian sales opportunities." Given the volumes of Canadian wood products being sold in "big box" retail outlets, e-Commerce represents a tremendous opportunity for value-added and primary wood products manufacturers to gain market access and maintain or enhance market shares (Ernst \& Young Press Release 1999).

\section{Objectives}

The Canadian value-added wood products sector should be poised to adopt e-Business solutions on a much wider scale and likely represents an attractive marketplace for IT and e-Commerce providers. The overall objective of this study is to determine whether or not the Canadian value-added wood products industry is ready to adopt and implement electronic commerce, content and communications solutions as a means of supporting and enhancing its business activities. Specifically, this study endeavoured to:

1. examine the current perception, adoption and future uses of computers and the Internet in the Canadian value-added wood products sector;

2. determine the current and future use of the Internet in business applications for the Canadian value-added wood products sector;

3. gauge the attitudes and beliefs towards the use of the Internet in business applications amongst Canadian value-added wood products sector; and

4. determine the Internet readiness of Canadian value-added wood producers, and based on these results, identify strategies for hastening the adoption of e-Business solutions.

\section{Methods}

In order to meet the research objectives, a facsimile survey was developed and implemented in late 1999. The sample frame used was obtained from the Industry Canada (Strategis) database, the most comprehensive and representative list of Canadian value-added wood producers available (Industry Canada 1999). Producers engaged in limited value-adding activities like milling and planing were excluded from the study, leaving a population total of 1364 value-added producers.

For the purposes of the research, the sample frame (1364 contacts) was used in its entirety. Given that the survey instrument was a facsimile questionnaire, contacts without fax numbers were dropped from the sample frame, leaving a total of 1216 value-added wood producers (key decision-makers in each company). ${ }^{4}$ While the population was sampled in its entirety, inferences must still be made, as this list does not represent all Canadian value-added wood producers.

A covering letter and facsimile survey were sent out in November 1999. The covering letter described the research project, solicited opinions and information from value-added wood producers and included notice of a draw prize in an attempt to increase response rates. The survey consisted of three sections: 1) general company information; 2) computer and Internet use; and 3) attitudes towards Internet use. Due to time constraints, limited pre-testing was conducted among academics and IT professionals. Changes were incorporated into the final version of the survey, which was faxed to companies on 15 November 1999 (with a cut-off date of 7 December 1999). Given the time and budgetary constraints involved in faxing over one thousand four-page surveys, only one version of the questionnaire was sent out to each of the companies.

\footnotetext{
${ }^{4}$ Given that this survey is on technology adoption, there may be concern that excluding value-added producers without fax machines would systematically bias the results. However, the companies that were excluded were only done so because their fax numbers were not easily obtained, and not because they lacked this technology.
} 


\begin{tabular}{lc}
\hline Table 1. Distribution of responses by province \\
\hline Province & Response Proportion \\
\hline Quebec & $24.8 \%$ \\
British Columbia & $18.8 \%$ \\
Ontario & $17.1 \%$ \\
Nova Scotia & $10.3 \%$ \\
New Brunswick & $7.7 \%$ \\
Saskatchewan & $7.7 \%$ \\
Manitoba & $6.8 \%$ \\
Alberta & $5.1 \%$ \\
Newfoundland & $0.9 \%$ \\
Prince Edward Island & $0.9 \%$
\end{tabular}

$\mathrm{n}=118$

Taking into account the companies that were unreachable by fax (214), the total number of companies that were surveyed was 1002 . Of these, 126 were returned ( 9 were spoilt) for a total response rate of $11.7 \%$. This was considered acceptable to make inferences onto the population of Canadian value-added wood producers, especially given the fact that there was only one mailout with no follow-up surveys.

While no follow-up surveys were sent out, response patterns indicate that little or no non-response bias was present in this research. In other words, results seem representative of the population under study and are, consequently, inferable to valueadded wood producers across Canada. For example, the regional breakdown of responses (Table 1) echoes the actual distribution of Canadian value-added wood production, with high levels of activity in eastern Canada and British Columbia and moderate levels in emerging sectors like Alberta, Saskatchewan, Manitoba, Nova Scotia and New Brunswick. Similar analyses were carried out on key variables like production and number of employees and gave no indication of nonresponse bias. Lastly, surveys were categorized into early and late responses and key study findings pertaining to computer and Internet use were compared using a series of two-tailed t-tests and z-tests $(\alpha=0.05)$. No statistical differences between early and late responses could be uncovered, further validating the assertion that non-response error is not present in the sample and that inferences onto the population of Canadian valueadded producers can safely be made.

\section{Results}

Results of this Canada-wide market study on Internet use amongst value-added wood producers in Canada are reported in five sections. While the facsimile survey consisted of three distinct sections (general company information, computer and Internet use and attitudes towards Internet use), results were collapsed in order to allow for more meaningful conclusions to emerge. The findings, as they pertain to the Canadian value-added wood producers, are reported as follows:

- production;

- computers and the Internet;

- Internet use;

- attitudes and beliefs towards Internet use; and

- late versus early adopters of the Internet.

\section{Production}

Fig. 1 illustrates the types of wood production that respondent companies are engaged in. The vast majority of respondents can be considered lower-level value-addition producers, manufacturing remanufactured goods (re-sawn, dried, or surfaced lumber products), mouldings, millwork, flooring, and miscellaneous other wood products (e.g., toys, signs, sheds). A fairly large proportion of producers also manufacture cabinetry-indicative of Canada's fast growing casegoods industry. Other higher value wood products like homes (e.g., modular, log, prefabricated), engineered wood products (e.g., truss, floor and wall systems, laminated beams) and doors and windows are also fairly commonplace. Lastly, pallets and boxes, furniture, fences and shakes and shingles each accounted for less than $5 \%$ of the responses.

More than one-half of the companies surveyed have less than twenty-five employees, with one-third having between ten and twenty-five (Fig. 2). An additional one-third employ between twenty-six and one hundred employees, with the remainder (only $12.8 \%$ ) employing over one hundred.

\section{Computers and the Internet}

Over one-half of the companies surveyed have five or less computers, with only a negligible proportion not having at least one. Just less than one-quarter of the respondents have more

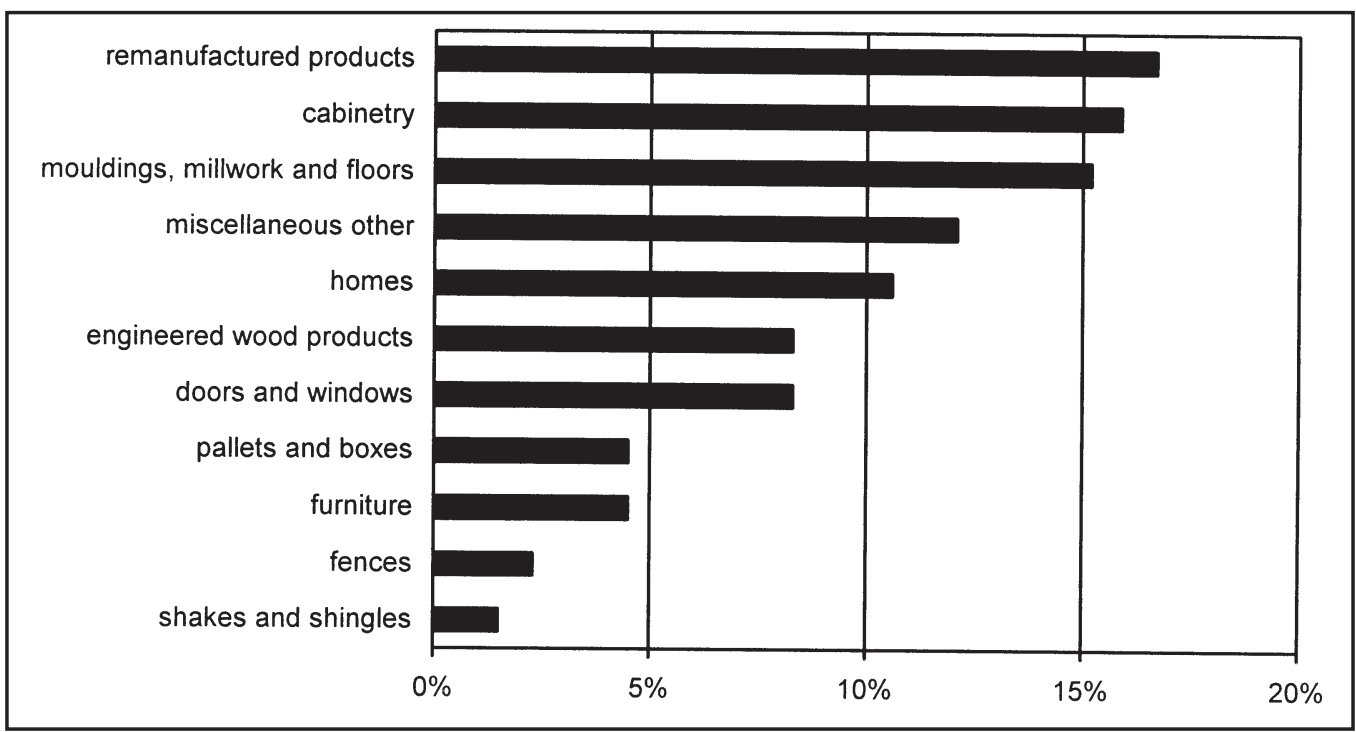

Fig. 1. Production by product type in surveyed Canadian value-added wood companies. 


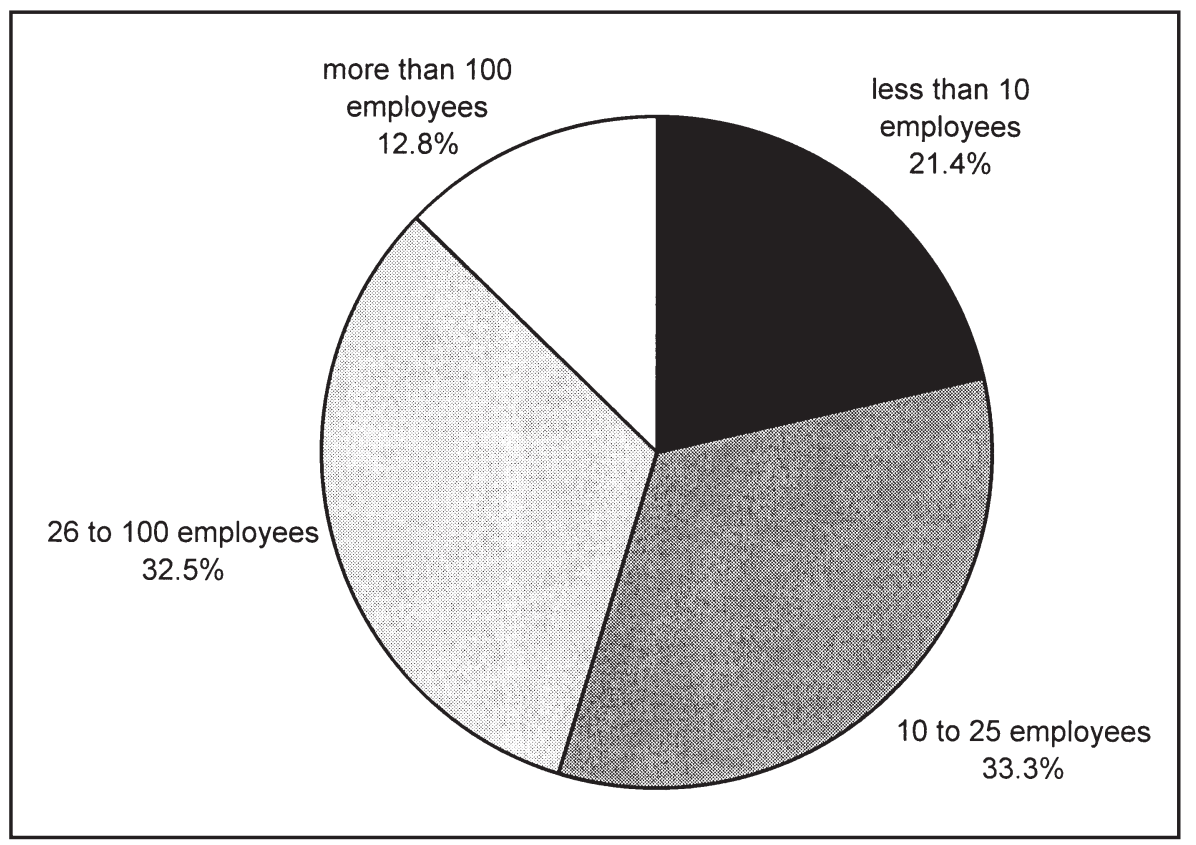

Fig. 2. Employment in surveyed Canadian value-added wood companies.

Table 2. Number of computers in surveyed Canadian value-added wood companies by company size

\begin{tabular}{lcrrr}
\hline & $\begin{array}{c}\text { Number of Computers } \\
\text { at Firms }\end{array}$ & \multicolumn{2}{c}{$\begin{array}{c}\text { Response } \\
\text { Proportion) }\end{array}$} \\
\hline $\begin{array}{l}\text { Firm Size (Number } \\
\text { of Employees): }\end{array}$ & None & $\mathbf{1 ~ t o ~ 5}$ & $\mathbf{6}$ to 10 & More than 10 \\
\hline less than 10 & $0.0 \%$ & $92.0 \%$ & $8.0 \%$ & $0.0 \%$ \\
10 to 25 & $5.1 \%$ & $69.2 \%$ & $25.6 \%$ & $0.0 \%$ \\
26 to 100 & $0.0 \%$ & $36.8 \%$ & $31.6 \%$ & $31.6 \%$ \\
more than 100 & $0.0 \%$ & $0.0 \%$ & $0.0 \%$ & $0.0 \%$ \\
\hline
\end{tabular}

than ten computers in their plants. Taking firm size into account (Table 2) shows the expected trend of an increasing number of computers as firm size increases, to the point where no firms with more than ten employees have less than ten computers. Interestingly, firms with less than ten employees are more likely to have at least one computer than firms with between ten and twenty-five employees. The majority of firms with between ten and one hundred employees have less than ten computers in their facilities.

More than $88 \%$ of the companies currently have Internet access (Fig. 3), with the vast majority having an access speed of over $28.8 \mathrm{~K}$ or more and over $40 \%$ having an access speed of $56 \mathrm{~K}$ or faster. More than one-quarter of the respondents did not know their Internet access speed, while only $1 \%$ were using out-dated $14.4 \mathrm{~K}$ technology. For $47.4 \%$ of the respondents, Internet access was through a line dedicated solely to the Internet, with the remainder (52.4\%) sharing with another device like a telephone or a fax machine. Lastly, it should be noted that of the approximately $12 \%$ of the respondents who are currently not on-line, $15 \%$ and $38 \%$ expected to have Internet access within three months and one year of receiving the survey, respectively. The remaining $47 \%$ (or just under $6 \%$ of all survey respondents) did not know if and when they will adopt this technology. That said, $51.5 \%$ of all of the companies surveyed currently have an active Web site in place.

\section{Internet Use}

On average, 5.7 people per company have access to the Internet, with a minimum of one and a maximum of 50 (yielding a $95 \%$ confidence interval of between 4.1 and 7.3 people per company). Not surprisingly, Internet use increases with firm size. The average number of people with access to the Internet in firms of varying sizes (and the respective 95\% confidence intervals) are: $2.5 \pm 0.7$ employees in firms employing less than ten; $3.0 \pm 0.6$ employees in firms employing between ten and twenty-five; $4.7 \pm 1.4$ employees in firms employing between twenty-five and one hundred; and 17.7 \pm 8.1 employees in firms employing greater than one hundred. It is notable that Internet access more than triples for firms with more than one hundred employees.

Over half of the users in the value-added sector access the Internet less than two hours per week (Fig. 4), with approximately $45 \%$ using the Internet less than one hour per week. Just less than one-third spend more than six hours per week on-line, with the remaining $10 \%$ at between three and six hours. These results were also segmented by firm size (not shown here); however, no trends that deviated from the overall averages could be uncovered. When asked how the company's Internet use will change in the next year, $78.4 \%$ of the respondents stated that it would increase, while $21.6 \%$ stated that it would stay the same. No respondents indicated that Internet use would decrease in the coming year.

When asked what types of business uses value-added wood producers utilized the Internet for, the overwhelming response was to conduct on-line research and to exchange documents with partners (Fig. 5). Communicating with customers through e-mail and obtaining business and product information also seem to be key drivers for Internet use. Of lesser importance, though still significant, are e-mailing with professional associations, obtaining news, and e-mailing with suppliers and distributors.

\footnotetext{
${ }^{5}$ Intranets represent a relatively new technology and many of the respondents may not have known what this term meant. Thus, this result should be viewed with some caution.
} 
no Internet access

$11.9 \%$

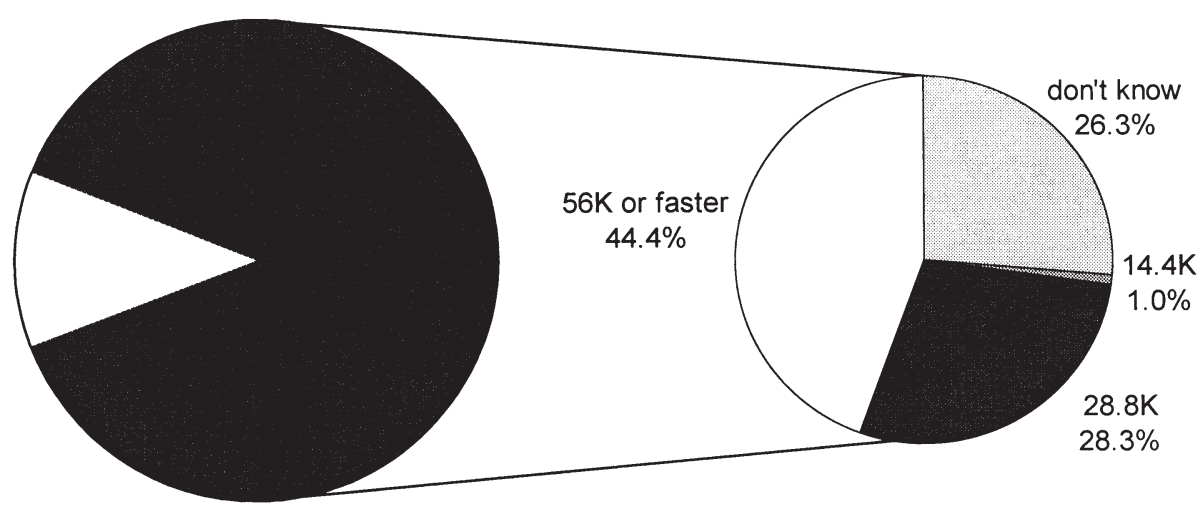

Internet access

$88.1 \%$

Fig. 3. Internet access of surveyed Canadian value-added wood companies.

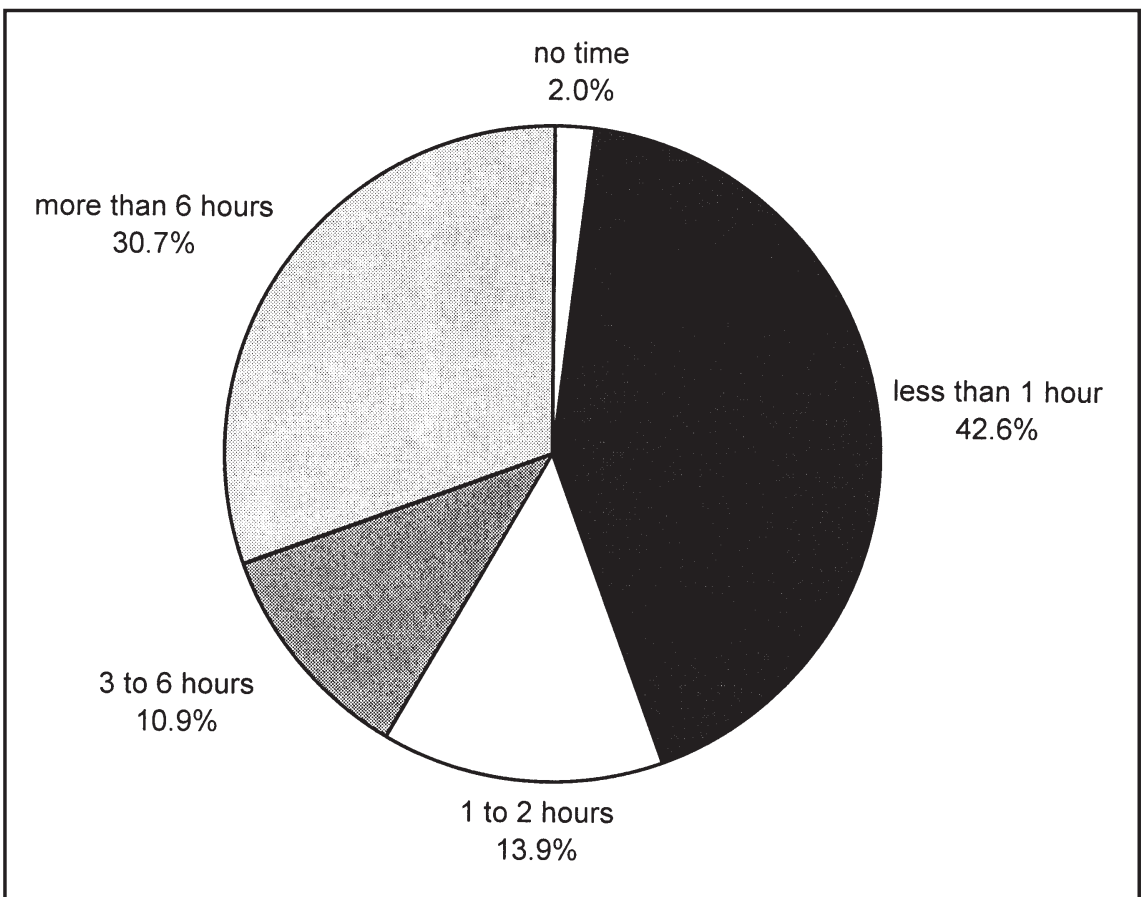

Fig. 4. Time spent on the Internet by average company users in surveyed Canadian valueadded wood companies.

Other than the aforementioned business uses, no other clear trend was noted, with the exception of three business activities that that are currently not widely practised on the Internet by the Canadian value-added wood products sector: e-mailing with employees, purchasing products on-line, and adopting intranet applications. ${ }^{5}$

In an attempt to measure and understand the degree to which business uses of the Internet were associated and concurrently adopted, a two-tailed Kendall's tau-b bivariate correlation analysis $(\alpha=0.05)$ was performed on the ordinal data set summarized in Fig. 5. The analysis yielded several significant correlations between the fifteen input variables (business uses of the Internet) - only three variables displayed relatively few significant correlations: downloading software, e-mailing employees and intranet applications. Most of the remaining variables were moderately correlated with each other at between 0.2 and 0.6 . This suggests some concurrent adoption of various business uses of the Internet, although most of the associations were not very strong (a score of 1 represents a perfect correlation between two variables). For example, performing on-line research is moderately correlated with e-mailing customers, distributors, suppliers and associations as well as electronic document exchange (a common use for e-mail). Companies that use the Internet to purchase products also tend to use this technology to track shipments. Companies that e-mail their own employees also use the Internet to enhance their customer service programs. While this latter correlation seems somewhat spurious, it does make some sense given that companies that use e-mail as a means of communication amongst their employees are likely to be larg- 


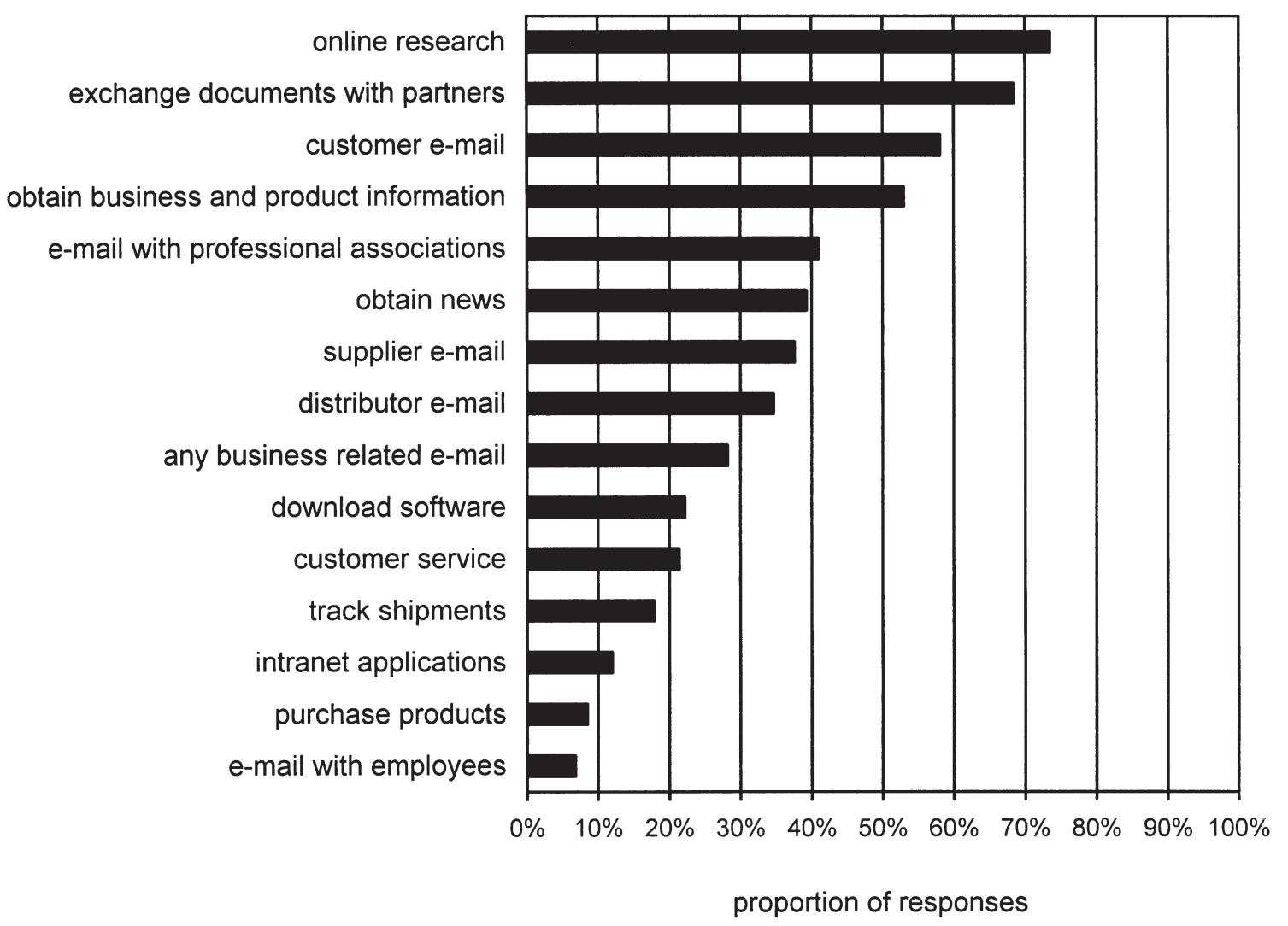

Fig. 5. Business uses of the Internet currently adopted by surveyed Canadian value-added wood companies.

Table 3. Attitudes and beliefs towards Internet use amongst surveyed Canadian value-added wood companies (expressed as average agreement level to the following statements, where $1=$ strongly agree, $3=$ neutral and $\mathbf{5}=$ strongly disagree)

The Internet has increased my supplier base.

The Internet has increased my customer base.

I feel comfortable buying products like books on the Internet.

The Internet will be used to increase my supplier base.

I would like to sell more products directly to customers using the Internet.

If the Internet had more information relevant specifically to suppliers, I would use it more.

The Internet will be used to increase my customer base.

If the Internet had more information relevant specifically to customers, I would use it more.

If the Internet had more information relevant specifically to the wood industry, I would use it more.

If all of my suppliers were on the Internet, I would use it more. If I can find customers using the Internet, I would use it more.

If all of my customers were on the Internet, I would use it more.

The Internet will become more important to my business in the next few years.

$*=$ significantly lower than a neutral score of $3(\alpha=0.05)$

er with more available resources for information technology. Lastly, the two most highly correlated variables $(0.586)$ were obtaining news and obtaining business and product information. This result is not surprising, suggesting that business activities related to using the Internet as a source of information have been concurrently adopted.

\section{Attitudes and Beliefs towards Internet Use}

In an attempt to gauge the attitudes and beliefs of Canadian value-added wood producers towards Internet use for business applications, respondents were asked to indicate their level of agreement with a number of statements using a standard interval Likert scale construction (strongly agree, agree, neither agree nor disagree, disagree, strongly disagree). As this scale approximates a true interval scale, means were computed and are seen in Table 3. Statements denoted with an asterisk were statistically lower than a neutral score of $3(\alpha=0.05)$, which is to say that the level of agreement for these statements was significant.

Most Canadian value-added wood producers agree with the fact that the Internet is becoming increasingly important to their businesses. Furthermore, they would use the Internet more often if their suppliers and customers were on-line, or if they were able to locate more customers. In general, value-added wood producers would use the Internet more often if it had more information relevant specifically to the wood industry, customers and/or suppliers. There seems to be a reasonable comfort level associated with carrying out transactions on the Internet and a desire to enable such business solutions. However, the results also clearly indicate that, to date, the Internet has not, by and large, increased their respective customer and supplier bases. While no other clear conclusions could be drawn beyond these findings, Table 2 does unquestionably illustrate that, in general, Canadian value-added wood producers are favourable to Internet usage as a means of conducting various levels of business activities. 
Table 4. Early versus late adopters amongst the surveyed Canadian value-added wood companies by product type

\begin{tabular}{lcc}
\hline Production & Early Adopters & Late Adopters \\
\hline remanufactured products & $33.3 \%$ & $66.7 \%$ \\
cabinetry & $57.1 \%$ & $42.9 \%$ \\
mouldings, millwork and floors & $64.7 \%$ & $35.3 \%$ \\
miscellaneous other products & $50.0 \%$ & $50.0 \%$ \\
homes & $78.6 \%$ & $21.4 \%$ \\
engineered wood products & $63.6 \%$ & $36.4 \%$ \\
doors and windows & $55.6 \%$ & $44.4 \%$ \\
pallets and boxes & $0.0 \%$ & $100.0 \%$ \\
furniture & $20.0 \%$ & $80.0 \%$ \\
fences & $33.3 \%$ & $66.7 \%$ \\
shakes and shingles & $0.0 \%$ & $100.0 \%$ \\
\hline
\end{tabular}

\section{Late versus Early Adopters of the Internet}

In an attempt to better understand the aggregate results of this research, responding firms were segmented into what could loosely be defined as early adopters of Internet technology (companies with active Web sites-51.5\%) and late adopters of Internet technology (companies that currently do not have a Web site-48.5\%). Key variables from each segment (production, number of employees, number of computers) were analyzed and are summarized in Tables 4 and 5. These results allow key differences between early and late Internet adopters in the value-added wood products sector to emerge.

For instance, in terms of production, some sectors of the valueadded wood products industry are clearly ahead of others in adopting Internet solutions (Table 4). Manufacturers of homes, mouldings, millwork, flooring, and engineered wood products, are clearly information technology leaders in this industry, followed by manufacturers of cabinetry, doors and windows. Conversely, sectors which produce lower priced goods like remanufactured wood products, miscellaneous wood products, pallets, boxes, fences and shingles are laggards. Curious in this analysis is the low rate of Internet adoption by the furniture industry, which manufactures arguably some of the highest-value consumer goods in the wood products sector. This anomaly may be attributed, in part, to the many mature, entrenched distributor and retailer relationships that currently exist in this sector and the perception that electronic marketplaces may be superfluous.

An analysis of the number of employees and computers that value-added wood producers have (Table 5) shows decisively that early adopters in this industry tend to be larger and devote more resources to information technology. The majority of firms surveyed with more than twenty-five employees have a Web presence and are categorized as early adopters, while the opposite is true for firms with twenty-five employees or less. The same trend is seen for companies with more than five computers at their disposal, especially as the number of computers increases beyond ten. In terms of employees' ability to go on-line, on average, $6.7 \pm 2.3$ employees (95\% confidence interval) have access to the Internet in early adopter companies, while $4.7 \pm 2.3$ employees ( $95 \%$ confidence interval) have access in late adopter companies. While a difference is noted, it is not statistically significant at the $\alpha=0.05$ level. In other words, the presence of a company Web site currently has little or no bearing on how many employees have access to the Internet at work.

\section{Discussion}

Many key findings have emerged from this market study on the state of Internet readiness and e-Business adoption in the Canadian value-added wood products sector. It is noteworthy that many of the results clearly point to an industry that has not yet adopted electronically based business solutions. Companies are currently in what could best be described as a "wait and see" or "anticipatory" stage with regards to Internet and e-Business applications. However, they are favourable to the use of the Internet as a means of conducting business. This may be in the form of B2B (business-to-business) solutions, in which the Internet is used to facilitate and intermediate transactions between companies at the industrial level or B2C (businessto-consumer) solutions, in which the Internet is used as a communicational and transactional medium between companies selling goods to consumers.

Certainly, a culture exists within the Canadian value-added wood products sector that is conducive the adoption of e-Business solutions. Most value-added wood producers have at least one computer in their facility, with over half having less than five at their disposal. The vast majority of manufacturers currently have Internet access, with many having state-of-theart access speeds, dedicated lines and multiple users. Perhaps most telling is the fact that just over half of the value-added wood producers surveyed have active Web sites in place. An informal survey of current Web sites revealed that they are primarily being used as a means of increasing visibility and providing timely information to their customers through brochure ware / advertising - not one responding value-added wood producer with a Web site that currently facilitates and enables financial transactions could be found. While it can be assumed that very few value-added wood producers expect not to have a Web presence in the near future, it has been estimated they presently spend less than $\$ 10000$ per year on information technology-not nearly enough to deploy an active e-Commerce solution and maintain a highly regarded Web presence (Kozak and McKinnon 2000). It is notable that companies that produce higher priced custom wood products (homes, cabinetry, mouldings, millwork, flooring, etc.) are more likely to have a Web presence than producers of lower value commodity goods. This trend also applies to larger companies.

In general, the Canadian value-added wood products sector has not yet taken advantage of what the Internet can offer with respect to improved business efficiencies along the supply chain. However, three-quarters of the value-added wood producers surveyed agreed that they would be using the Internet more frequently in the future to conduct business. Currently, the most common uses of the Internet for business applications among value-added wood producers are for conducting on-line research and exchanging documents with partners, followed by communicating with customers and obtaining product and business information (the Internet is cited as one of the most common sources of information). The least common uses include e-mailing employees, purchasing products on-line and adopting intranet solutions. Many of these business activities have been adopted concurrently-the use of the Internet for e-mailing and information retrieval, for example.

It is noteworthy that these results are largely in keeping with data compiled for all business sectors (Clemente 1998). In order, the most common Internet business applications across all sectors include conducting on-line research, sending and 
Table 5. Average proportions of employees and computers for early versus late adopters in the surveyed Canadian value-added wood companies

\begin{tabular}{|c|c|c|c|c|c|}
\hline Number of Employees & Early Adopters & Late Adopters & Number of Computers & Early Adopters & Late Adopters \\
\hline less than 10 & $45.0 \%$ & $55.0 \%$ & none & $0.0 \%$ & $100.0 \%$ \\
\hline 10 to 25 & $43.2 \%$ & $56.8 \%$ & between 1 and 5 & $39.3 \%$ & $60.7 \%$ \\
\hline 26 to 100 & $60.6 \%$ & $39.4 \%$ & between 6 and 10 & $60.9 \%$ & $39.1 \%$ \\
\hline more than 100 & $66.7 \%$ & $33.3 \%$ & more than 10 & $74.1 \%$ & $25.9 \%$ \\
\hline
\end{tabular}

receiving business e-mail, obtaining news, downloading software (especially for small companies), exchanging software (excluding small companies), exchanging documents (excluding small companies), e-mailing with professional associations, obtaining business product information, e-mailing with employees (excluding small companies), and intranet applications (especially large companies). Canadian value-added producers differ from these industry benchmarks in that they seem to place a great deal more importance on customer, supplier and distributor e-mail, and less importance on other business-related e-mail. In addition, obtaining news and downloading software is of lesser importance to value-added wood producers, while obtaining business and product information and exchanging documents with partners is of greater importance. Finally, e-mailing employees within organizations, Internet customer service, purchasing products on-line and intranet applications are not at all common.

The Canadian value-added wood products sector is characterized by a high degree of competition and fragmentation. They manufacture a wide range of goods, from remanufactured lumber products to high-end furniture and homes. However, with the exception of cabinetry, the most commonly produced goods in Canada tend to be low-level value-addition products like remanufactured lumber products, mouldings, millwork and flooring. In addition, they generally have broad customer bases, concentrated primarily in North America. That said, there does seem to be a reliance on personal networks and entrenched partnership arrangements with a narrow base of primary producers, downstream distributors and retailers. In short, Canadian value-added wood producers have many of the attributes of a sector at the verge of adopting Internet business solutions on a wide scale.

However, Canadian value-added wood producers tend to be small and labour-intensive, with more than half having less than twenty-five employees. This presents a serious hurdle with respect to the adoption of Internet business solutions. Many producers simply do not have the resources available to build and maintain e-Commerce solutions in-house. Fortunately, one model for the new economy that is rapidly gaining momentum is the third-party vertical Internet portal. Many such portals exist in the solid wood industry ${ }^{6}$, but few are devoted to providing B2B solutions between the primary and value-added wood industries. The Canadian value-added wood products sector represents a prime market opportunity for a sophisticated vertical Internet portal providing content, communication and commerce services. It is serendipitously positioned at the nucleus of the forest products value chain, with a narrow group of primary wood producers / suppliers feeding into production and a much wider net of distributors / retailers occurring downstream. There appears to be a definite need for a centrally administered

${ }^{6}$ TALPX.com, forestexpress.com, iLumber.com, forestindustry.com, eWood.com, to name a few examples. on-line source of market information. In addition, producers are currently looking for new ways of communicating more efficiently and effectively with the many actors in the supply chain (including end-users). Lastly, manufacturers seem amenable to exploring electronic commerce possibilities and opportunities with their customers.

In fact, the realm of possibilities with respect to e-Business strategies is virtually limitless. Sophisticated Internet portals all offer some level of commerce, communication, and content provision. In addition, brochure ware and advertising, credit mechanisms, searchable databases, information security features, access to shared inventories, automatic re-ordering, supply chain management, new market development, various transactional models (from direct sales to auctions), market information, and human resources tools are a few examples of common applications in the new economy. The third-party portal allows these tools and applications to be easily accessed, even by small value-added wood products companies with limited IT budgets.

Lastly, it should also be noted that, while this research was not conducted on value-added wood producers in the United States, many of the results could be extrapolated due to similarities in industry structure, production and consumption. Furthermore, due to the unique position of the value-added wood industry within the wood products value-chain, this research provides a solid foundation and context for further studies within the wood industry; most notably in the lumber and the panel sectors, but also in the areas of intermediation, specification and retail. In fact, the appropriate strategy for hastening the adoption of Internet technologies amongst value-added wood producers would be to "bring them along" somewhat by demonstrating the benefits of e-Business all along the value chain. In other words, if their customers and suppliers were using on-line business tools, the likelihood of adoption would undoubtedly increase.

\section{A Comment on Study Limitations}

Research relating to the adoption of the Internet and electronically based business practices is complicated by the rapid rate at which the new economy is evolving. As such, the findings of this study, based on a survey conducted in late 1999, should be viewed with some caution - the data reported here are dated and may, in some instances, lack relevance in an abruptly changing world. In 1999, the Internet held both promise and mystery for businesses, while in 2001, the reality of having to deploy tangible but profitable electronic business solutions has set in. That all said, studies on Internet readiness and e-business adoption of Canadian value-added wood producers are few and far between. At the very least, this work provides useful benchmark information and a historical perspective on how the new economy has impacted an important and growing economic sector of Canada at a critical juncture in its growth. More importantly, it forms a basis for future studies on Internet adoption in the Canadian value-added wood products sector. 


\section{Conclusion}

With its abundance of high-quality fibre and its proximity to massive markets, the Canadian value-added sector is uniquely positioned to become a global market leader in the production and sale of wood products. However, with its modest attitudes towards the adoption of Internet technology and e-Business initiatives, this sector may best be characterized as a "late majority" or perhaps even a "laggard." This can be seen as both a drawback and an opportunity. On one hand, the adoption of Internet technologies to facilitate exchange will require a paradigm shift to a certain degree. On the other hand, the value-added wood products sector seems willing to adopt Internet solutions and, in fact, the argument can be made that they must do so quickly in order to remain competitive in an industry that is becoming more and more aggressive in the acquisition and maintenance of customers. Add to this the trend towards electronic retailing, and the need for wood products companies to incorporate Internet solutions in this sector becomes crucial.

In the final analysis, the question still remains: "are Canadian value-added wood producers ready to adopt Internetbased strategies for conducting business?" This market study has decisively shown that there has been no widespread adoption of e-Business solutions in this sector. However, the upside is that there is a general feeling that the new economy is fast approaching and companies seem to be bracing themselves for that eventuality by gearing up from a technological point of view. Although current IT expenditures are low, they do nonetheless appear on balance sheets. This can only be taken as a positive sign, especially in light of the fact that there already exists a fairly healthy "computer culture" among value-added wood producers, especially higher value wood producers and larger firms, many of whom already have Web sites in place. That said, success will largely depend on whether or not Canadian value-added wood producers view the adoption of Internet-based business solutions as being a worthwhile endeavour in terms of increased profits, expanded markets, improved supply chain efficiencies, and so on. In light of the current economic climate, this may prove to be a formidable and challenging task.

\section{Acknowledgements}

The author wishes to thank the team at Vertico Networks, Inc. for their guidance and funding of this research project.

\section{References}

Clemente, P.C. 1998. State of the Net - The New Frontier. McGrawHill, New York, New York. 179 p.

Ernst \& Young. 1999. Ernst \& Young Releases 18th Annual IT Survey. Toronto, October 27, 1999.

Forrester Research. 1999. <http://www.forrester.com/Home/ $0,3257,1, \mathrm{FF} . h \mathrm{tml}>$.

Industry Canada - Strategis. 1999. <http://strategis.ic.gc.ca/SSG/ gi00025e.html>.

Industry Canada - Strategis. 2001. <http://strategis.ic.gc.ca〉.

Kozak, R. and T. McKinnon. 2000. VAWP Market Study - Internet Use Amongst Canadian Value-Added Wood Producers. Prepared for Vertico Networks, Inc. $64 \mathrm{p}$.

Statistics Canada. 1998. <http://www.statcan.ca>.

PriceWaterhouseCoopers. 1999. Global Forest \& Paper Industry Survey, 1999 Edition. pp. 50-51.

PriceWaterhouseCoopers. 2000. Press Release - Business Wire. Vancouver, January 10, 2000.

Vlosky, R.P. 1999. eBusiness in the forest products industry. Forest Products Journal 49(10): 12-21.

Vlosky, R.P. and R. Fontenot. 1997. The Internet and the forest products industry: current status and projected trends. Forest Products Journal 47(11/12): 33-40.

Vlosky, R.P. and O.T. Pitis. 2001. eBusiness in the forest products industry: A comparison of the United States and Canada. For. Chron. 77(1): 91-95. 